\title{
An integrated landscape approach for socially inclusive peatland restoration
}

\section{TIMOTHY JESSUP ${ }^{1}$, MARCEL SILVIUS ${ }^{1}$, HENDRIK SEGAH ${ }^{1,3, *}$, GRAHAME APPLEGATE $^{2}$, YUSURUM JAGAU ${ }^{3}$, CHRISTOPHER BENNETT $^{1}$}

\author{
${ }^{1}$ Global Green Growth Institute (GGGI), Indonesia Program, Gedung Lippo Kuningan, Jl. H. R. \\ Rasuna Said Kav. B-12, Lantai 19, Jakarta 12940 - Indonesia. \\ ${ }^{2}$ University of the Sunshine Coast, Tropical Forests and People Research Centre, 4557, Maroochydore, \\ Australia \\ ${ }^{3}$ Center for International Cooperation in Sustainable Management of Tropical Peatland (CIMTROP), \\ University of Palangka Raya, Jl. Yos Sudarso, Kampus UPR Tunjung Nyaho, Palangka Raya 73111, \\ Central Kalimantan - Indonesia.
}

\begin{abstract}
Successful restoration and fire prevention in peat landscapes require full rewetting and permanent revegetation for optimal water retention. The ecological and socio-economic heterogeneity of these landscapes calls for integrated approaches based on participatory zonation and locally appropriate business models. Primary activities in deep-peat core zones are blocking of drainage canals and revegetation; in shallow-peat buffer zones, forestry and agroforestry on fully rewetted peat, aquaculture, and duck farming; while on surrounding non-peat mineral soils, more intensive tree plantations and agriculture. Community-oriented enterprises require private investment, including microfinance. Blended public and private investment is needed for core-zone restoration. Assuming restoration costs of USD 250-1,000 per ha on moderately drained peat, with emissions of $40 \mathrm{tCO}_{2} / \mathrm{ha} / \mathrm{year}$, carbon finance could pay for the cost of restoration in under 10 years if emissions are fully or largely abated. To stimulate investment in multiple peatland landscapes we propose a provincial 'enabling platform' to support participatory zoning, project design, and monitoring based on common standards and methodologies; technical assistance and incubation for project start-up; multi-stakeholder support for enabling policies, plans and institutions; strengthened finance mechanisms and bundled investments for large and small enterprises; and robust scientific support and knowledge exchange.
\end{abstract}

Key words: Central Kalimantan, Greenhouse gases, Land scape approach.

\section{INTRODUCTION}

Peatlands are very important globally for the provision of ecosystem services, most notably carbon storage and the natural regulation of water flow (Joosten 2009). Peatlands play a critical role in mitigating climate change because of their vast stocks of soil organic carbon. Indonesia, which has the largest area of tropical peatlands, is estimated to hold around $28 \mathrm{Gt}$ of carbon, or

Correspondence Author: Hendrik Segah, Global Green Growth Institute (GGGI), Indonesia Program, Gedung Lippo Kuningan, Jl. H. R. Rasuna Said Kav. B-12, Lantai 19, Jakarta $12940 \quad$ - Indonesia, Email: hendrik.segah@gggi.org more than one-third of the global tropical peat carbon pool (Warren et al. 2017). While only $6 \%$ of land-use in Indonesia is based on peat soils, often with limited productivity, the related emissions contribute close to half of Indonesia's total carbon footprint (GoI 2018). For this reason, reducing or preventing the emissions of GHG from tropical peat is of key importance as a costeffective option for climate change mitigation (Miettinen et al. 2017).

Since the 1980s, large areas of Indonesia's peat swamp forests have been drained for agriculture and forestry (Miettinen et al. 2016). The crop species 
commonly grown in plantations and by smallholder farming on peat soils require drainage, which causes the peat to become dry and so leads to peat degradation, peat decomposition, and increased fire risk. Degradation of Indonesia's peatlands has created the conditions for major fire events affecting millions of hectares of land and creating international smog-haze events affecting tens of millions of people (Miettinen and Chin Liew 2010). The fire and haze event in 2015was estimated to have caused US\$ 16.1 billion in economic damages to Indonesia's economy (World Bank 2016).

Drainage also results in peatland subsidence, as a result of soil compaction, shrinkage and loss of carbon, which enhances flood risks. With the continuation of current drainage-based land-use, large areas of Sumatra and Kalimantan will become increasingly subject to future waterlogging and flooding, including salt water intrusion in coastal lowland areas, because of ongoing subsidence. Coupled with ongoing fire risks, there is a strong likelihood that most of these landscapes will eventually become unsuitable for agricultural or forestry use, unless action is taken to change course (Hooijer et al. 2015a, 2015b). Emissions and soil subsidence may be slowed and eventually stopped through restoration of the eco-hydrology of the peatland. This requires not only rewetting through blocking or filling of drainage canals but also the establishment of a permanent vegetation cover with trees (to enhance water retention capacity and micro-climatic conditions for emission reduction and carbon sequestration) and revitalization of the livelihoods of people living in and around the peatlands (Giesen and Nirmala 2018, Dohong et al. 2018, Page et al. 2009). The recent recurrence of peatland fires is a reminder that, despite many well-intended but too often fragmented efforts at peatland restoration and protection, a truly integrated landscape approach will be needed across much of Indonesia's peatlands.

\section{AN INTEGRATED LANDSCAPE APPROACH TO PEATLAND RESTORATION}

With the need for a landscape-wide approach to restoration-that is, full rewetting, revegetation, and economic revitalization (embodied in the '3-Rs' paradigm of the Indonesian Peatland Restoration Agency) - an integrated landscape zoning model for the development of business-based enterprises within these landscapes is appropriate GGGI 2018, Giesen and Nirmala 2018). The model is based on the restoration of degraded and fireprone deep peat within a core protection zone, surrounded and supported by a substantial production zone on shallower peat in which local communities and businesses undertake complementary land use activities on rewetted peat. The production zone can encompass profitable community-based and private sector forestry, agroforestry and other enterprises that provide livelihoods for farmers as well as a reasonable return on commercial investment. The efforts need to be business-based to ensure continued positive incentives for landscape restoration and protection.

Effective land use zonation helps to resolve conflicts between administrative status and societal values and functions of landscapes (Bennett and Suhardi 2017). Land use zonation should establish the social and legal legitimacy of the "where" of interventions before initiating the "what" of sustainable landscape interventions and be readily understood by all stakeholders 
therefore conducted at a small-enough scale to be aligned as far as possible with recognizable topographical features (USAID-LESTARI 2018a). This in turn provides opportunities for identifying local technologies and processes that can be integrated into more scientific interventions (Bennett 2002). It is essential that the three peatland landscape zones-protection, limited production, and more intensive production (on surrounding non-peat soilsbe respected by stakeholders in the landscape, as the zonation is the guiding basis for land-use and water management. This means that the zonation scheme depends upon recognition of appropriate stakeholder rights, responsibilities and relationships. Stakeholders must agree on the metrics or indicators of success for peatland restoration.

Therefore, an integrated landscape approach to peatland restoration relies on genuinely participatory zonation following the principles of free, prior and informed consent (FPIC, in Indonesian Padiatapa) aligned with the ecological requirements of working across a whole peatland hydrology unit (kawasan hidrologis gambut, or KHG). Genuinely participatory planning helps to build trust among the many and varied stakeholders in the landscape, notably local government, sectoral agencies, private sector license holders, and residents of local communities (USAID-LESTARI 2018b). Failure to achieve proper FPIC risks a plethora of well-meaning but improperly coordinated series of activities, ranging from peat rewetting to paludiculture and sufficiently responsive fire surveillance and fire suppression, that can only succeed if all parties are clear about the definition and delineation of the zones and willingly take steps to respect them. The final step of participatory zonation is to ensure that biophysical and social legitimacy are strengthened by legal legitimacy within the framework of formal planning instruments, e.g., the "blocking" or zonation in the longterm development plan of the responsible forest management units (FMU in English; kesatuan pengelolaan hutan, or $\mathrm{KPH}$, in Indonesian). The zonation should be reflected in the formal village development plans (RPJMD) of communities in the landscape. Subsequent major infrastructure developments, particularly canal blocking (by fixed dams, infilling or sluices), should also be subject to FPIC at the design stage, lest inappropriate structures be designed and constructed.

Restoration with productive economic outcomes on peatlands requires alternative land-use (agriculture and forestry) systems under wet conditions, known as paludiculture (Giesen 2013). This will protect the peat carbon store, reduce the risk of fires, reduce soil subsidence and thus future flooding, and provide economic development prospects including investment from the carbon sector. A range of agroforestry options are available, depending on the management objectives and sitespecific conditions such as hydrology, peat characteristics, current land use and land-use policy, land tenure, and the priority given to conservation or protection (GGGI 2018). Over 500 indigenous peat swamp plant and tree species with known uses have been identified and about 80 have been shortlisted for paludiculture development (Giesen 2013). It is therefore warranted to start planning for a responsible phasing-out of drainage-dependent crops and introduction of alternative, wetland crops before soil subsidence has progressed too much. This will require piloting of such alternative developments supported by investment in research and development, market 
development, and appropriate financing mechanisms for blending of public and private investments, fund distribution (e.g. micro-finance) and de-risking facilities.

The box below shows, in schematic form, the design elements of an integrated landscape project encompassing ecosystem restoration and protection together with productive economic activities in and around a peatland hydrological unit (KHG), which - in view of the high hydrological connectivity within peatland ecosystems - is the minimum area within which peatland restoration and management can work successfully. Restoration is comprised of rewetting degraded peatland areas by blocking and filling in drainage channels, revegetating or reforesting these areas, and revitalizing the livelihoods of people in communities in and around the peatlands. Initial re-wetting can often be accomplished in a few months, depending on how fast and in which season canals are blocked. Reforestation can take much longer, depending on the desired end state, which could be a fully-grown forest to store carbon, a productive (paludiculture) agro-forestry plantation, or combinations of these. Restoration of a permanent vegetation cover enhances the effectiveness of rewetting and thus fire prevention and reduction of peat carbon oxidation, as it enhances microrelief and thus water retention capacity; it also enhances the micro-climate including reduced temperature and elevated air moisture. Economic revitalization can be undertaken in phases that yield benefits in short, medium, and longer time-frames.

Improving community livelihoods on non-peat soils and in the shallow peat in the buffer zones will help secure local support for protection and restoration within the deeper peat areas, which in turn will contribute to the maintenance and restoration of ecosystem services, including the carbon storage function essential to achieving Indonesia's NDC goals. This can be further advanced through the legal recognition and protection of legitimate tenurial rights, including customary rights (hak adat) over land in some areas as well as utilization licenses (e.g. social/community forests), but also apprehending of illegal logging and drainage-based land-use expansion into fragile peatland areas. Transparency about land tenure rights and claims will also enhance stakeholder involvement and investor confidence in land-use development and peatland restoration.

\section{FINANCING PEATLAND RESTORATION}

The World Bank has estimated the initial cost for rewetting 2 million hectares to be around USD 2 billion, but this does not include the recurrent costs of long-term management or the costs to businesses that must relocate or reorient their activities (World Bank 2016). Some costs can be borne by land-owners and concession holders, but the legally occupied peatlands do not cover even half of the most critically degraded peatlands. Central Kalimantan alone has nearly 1 million ha of degraded peatlands that are urgently in need of restoration and which do not fall within existing concessions. Consideration should also be given to the fact that the costs of business as usual or doing nothing by far exceeds the costs of restoration, with each $\mathrm{El}$ Niño event bringing the risk of many billions of US\$ in social and economic damages to Indonesia and its neighboring countries.

Given the large amount of carbon stored in peatlands, together with the widely recognized value of avoided GHG emissions, there is a substantial but as yet largely unrealized business potential to access large- 


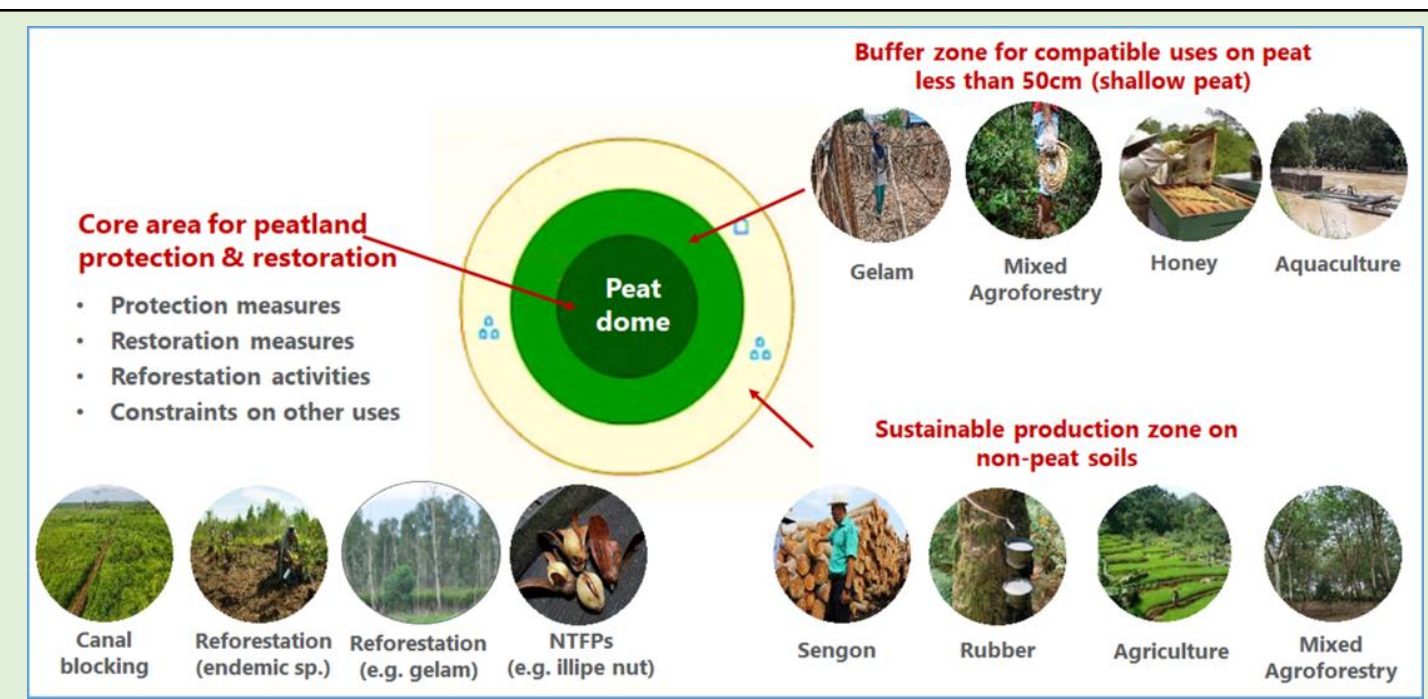

A business-based integrated landscape approach is required to restore the vitality of peatlands due to the eco-hydrological interconnection and dependence between the various land-systems in a peat landscape and the spillover effects of different landuses on adjacent areas. The flow of water over and through the peatland and its surroundings defines the "hydrological unit," (KHG) as the minimum land-scape unit within which the natural resource base needs to be managed in a coordinated and integrated manner. The diagram shows enterprises that can be carried out in different parts of the landscape, including some more intensively managed areas on mineral soils to reduce unsustainable pressures on the peatlands.

Figure 1. Spatial landscape design for peatland restoration, protection and development

scale financing from carbon markets and related finance such as carbon markets and other results-based payment schemes. A few site-based projects have already begun to demonstrate how carbon markets can be used to access finance for restoration of peatland areas in Indonesia.

A blend of public and private finance is needed for investment in peatland restoration combined with suitable business models based on payments for carbon and other ecosystem services, paludiculture on rewetted peat, and intensified production of agriculture or agroforestry on adjacent nonpeat soils. The significant public benefits of protecting productive peatlands and avoiding the costs of fire, haze, floods, and GHG emissions warrant a substantial investment of national and international public funds to rectify the problems caused by mistaken policies of the past and to encourage additional, private investment in suitable business opportunities in and around restored peatlands. Indonesia has recently seen a sharp uptake of green bonds as a financing mechanism for green or climate changeoriented projects.

Sovereign bonds could be useful to enhance the financing capacity for peatlands restoration work at a large scale, with the economic return for the government coming mainly in the form of reduced costs of fire and haze together with the value of ecosystem services (including emissions reduction and maintained land productivity through reduced soil subsidence) and the social welfare benefits of green growth development. International finance for climate mitigation and adaptation efforts may further facilitate and reward such positive development. 


\section{BUILDING A PROVINCIAL ENABLING PLATFORM}

A provincial enabling platform is proposed to catalyze the restoration, conservation, and sustainable management of more than 2 million ha of peatlands in Central Kalimantan. A province-wide approach is warranted, first, because it will help make site-based peatland restoration efforts in individual landscapes legally and financially secure, thus encouraging more and longer-term investment from both private and public sources. Second, the platform will ensure that these and other mitigation actions in the province are well coordinated and aligned with government systems and priorities, particularly Indonesia's peatland policies and the Nationally Determined Contribution (NDC) as well as Indonesia's priorities in regard to fire prevention.

The provincial platform will foster and support a growing number (possibly up to 20) of landscape-wide restoration projects, each covering up to several hundred thousand hectares, through an integrated landscape approach that balances development with the need to conserve intact peat swamp forest ecosystems. The platform will provide a range of supportive actions, facilitation, and technical services:

- Support for project design and monitoring (aligned with the national MRV system) based on common standards and methodologies;

- Technical assistance and incubation facilities for project and enterprise startup;

- Multi-stakeholder support for enabling policies, plans, and institutions;

- Access to finance mechanisms to bundle investments for large and small enterprises;
- Robust scientific support and knowledge exchange among national and international institutions.

Individual landscape-wide projects can be developed, financed, and managed by a variety of proponents and investors. Several such projects are either already operational or in various stages of design and development in Central Kalimantan.

The platform will support the development of enabling policies and conditions conducive to long-term, socially inclusive investment in peatland restoration, thus de-risking legitimate and sustainable peatland management by communities, concession-holders, and government management units. Certain outputs are intended to encourage or (where appropriate) require best practices; others create windows to obtain financial and technical support for business-based approaches to peatland restoration; while some are aimed at strengthening the capacity of institutions and safeguards and will build systematic linkages from site-based activities and outcomes to sub-national and national systems.

A concurrent objective of building the platform is to pilot and demonstrate methods that can be replicated in other peat-rich provinces of Indonesia. Central Kalimantan will thus develop the first province-wide approach to peatland restoration and management in Indonesia, paving the way for other key peatland provinces. At the same time, best practices and experiences will be drawn from and exchanged with other provinces and countries as a basis for designing and strengthening the work in Central Kalimantan and Indonesia as a whole and contributing to the NDC, SDGs, and the Global Peatland Initiative. 


\section{CONCLUSIONS}

Indonesia's peatlands are globally important as a provider of ecosystem services, notably the provision of water and carbon sequestration, but as a consequence of mismanagement they have become a major source of GHG emissions, smokehaze, and flooding. Restoration of degraded peatlands is an urgently needed and costeffective solution to these problems. An integrated, participatory landscape approach based on sustainable, restorative business models that benefit local stakeholders shows promise, but despite positive policy reforms and laudable efforts, the approach has yet to be demonstrated at a sufficiently largescale to be effective.

The financing needs to successfully restore and protect more than 2 million ha of Indonesia's degraded peatlands are large, but so are the potential economic, social, and environmental benefits. Innovative financial instruments and 'blended finance' from public and private sources are needed. There is ample scope for climate finance to play a role, including carbon trading, if the right enabling policies are put in place. Indonesia's peat-rich provinces would benefit from the creating of 'enabling platforms' that facilitate collaboration among project proponents, investors, government regulators, and communities and that provide the needed finance, technical assistance, capacity building, and knowledge exchange to restore and protect peatlands on a large scale.

\section{REFERENCES}

Bennett, C.P.A. (2002) Of "Responsibility," Accountability and National Unity. In, "Which Way Forward: People, Forests, and Policymaking in Indonesia", Colfer,
C.J.P. and Resosudarmo, I.A.P. (eds.). Resources for the Future (RFF) \& Centre for International Forestry Research (CIFOR), Washington, D.C, Chapter 3.

Bennett, C.P.A. and Suwardi,S. (2017) Overcoming Conflicts between Land Use Status and Function: Intersectoral collaboration at the local landscape level. Jurnal LESTARI, Vol.2, 2, 21-35.

Dohong, A., Aziz, A. A., \& Dargusch, P. (2018). A review of techniques for effective tropical peatland restoration. Wetlands, 1-18.

GGGI. (2018) GGGI (2018) Investment options for mixed agroforestry projects on peatlands in Indonesia. Global Green Growth Institute, Jakarta.

Giesen, W. (2013). Paludiculture: sustainable alternatives on degraded peat land in Indonesia (revised draft). Quick Assessment and Nationwide Screening (QANS) of Peat and Lowland Resources and Action Planning for the Implementation of a National Lowland Strategy. PVW3A10002. Agentschap NL 6201068 QANS Lowland Development. Euroconsult Mott MacDonald \& Deltares. For: Bappenas \& Ditjen Sumber Daya Air, PU, Government of Indonesia. Jakarta, 71 pp.

Giesen, W., and Nirmala, E. (2018) Tropical Peatland Restoration Report: The Indonesian Case. Berbak Green Prosperity Partnership, MCA-Indonesia, Jakarta.

GoI. 2018. Indonesia: Second Biennial Update Report under the United Nations Framework Convention on Climate Change. Government of Indonesia. Jakarta.

Hooijer A, Vernimmen R, Visser M, Mawdsley N, 2015a. Flooding projections from elevation and subsidence models for oil palm plantations in the Rajang Delta peatlands, Sarawak, Malaysia. Deltares report 1207384, $76 \mathrm{pp}$.

Hooijer, A., Vernimmen, R., Mawdsley, N., 
Page, S., Mulyadi, D., Visser, M., 2015b. Assessment of impacts of plantation drainage on the Kampar Peninsula peatland, Riau. Deltares report 1207384 to wetlands International, CLUA and Norad.

Joosten, H. 2009. The Global Peatland $\mathrm{CO}_{2}$ Picture: peatland status and drainage related emissions in all countries of the world. Wetlands International, The Netherlands. pp.35

Miettinen, J., Hooijer, A., Vernimmen, R., Chin Liew, S., S.E. Page, 2017. From carbon sink to carbon source: extensive peat oxidation in insular Southeast Asia since 1990. Environ. Res. Lett. 12 (2017)

024014,

https://doi.org/10.1088/1748-

9326/aa5b6f

Miettinen, J., Shi C., Liew, S.C. 2016. Land cover distribution in the peatlands of Peninsular Malaysia, Sumatra and Borneo in 2015 with changes since 1990. In: Global Ecology and Conservation 6 (2016) 67-78

Miettinen, J, Hoojier, A, Tollenaar, D, Page, S, Malins, C, Vernimmen, R, Shi, C \& Liew, SC 2012, Historical analysis and projection of oil palm plantation expansion in peatland in Southeast Asia, CSISP, National University of Singapore, in: Dohong et al 2012, p.352.

Miettinen, J., Hooijer, A., Vernimmen, R., Chin Liew, S., S.E. Page, 2017. From carbon sink to carbon source: extensive peat oxidation in insular Southeast Asia since 1990. Environ. Res. Lett. 12 (2017)

024014,

https://doi.org/10.1088/17489326/aa5b6f.

Miettinen, J. and Soo Chin Liew. 2010. Status of Peatland Degradation and Development in Sumatra and Kalimantan. AMBIO A Journal of the Human Environment 39(5-6):394-401. DOI: $10.1007 / \mathrm{s} 13280-010-0051-2$.

Page, S., Hosciło, A., Wösten, H., Jauhiainen, J., Silvius, M., Rieley, J., ... and Limin, S. (2009). Restoration ecology of lowland tropical peatlands in
Southeast Asia: current knowledge and future research directions. Ecosystems, 12(6), 888-905.

USAID-LESTARI. 2018a. Participatory Zonation: Participatory Land Use Zonation in State Forest Areas Providing Smallholder Land Security that Supports Biodiversity Conservation. LESTARI Brief, 30 June 2018.

USAID LESTARI. 2018b. FPIC: Lessons Learned from effective FPIC for Canalblocking as a Fundamental Enabling Condition of Peatland Restoration. LESTARI Brief, 30 June 2018.

Warren, M, Hergoualc'h, K, Kauffman, J., Murdiyarso, D., and Kolka, R. 2017. An appraisal of Indonesia's immense peat carbon stock using national peatland maps: uncertainties and potential losses from conversion. Carbon Balance and Management 12:12. DOI 10.1186/s13021-017-0080-2

World Bank. 2016. The cost of fire: an economic analysis of Indonesia's 2015 fire crisis (English). Indonesia sustainable landscapes knowledge; note no. 1. Washington, D.C. : World Bank Group.

http://documents.worldbank.org/curated/ en/776101467990969768/The-cost-offire-an-economic-analysis-of-Indonesias-2015-fire-crisis 